
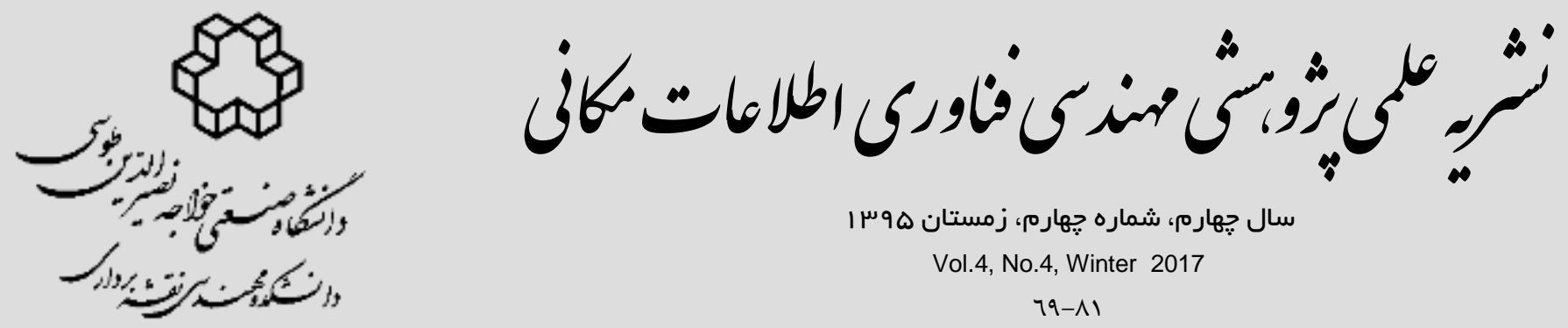

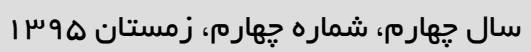

Vol.4, No.4, Winter 2017

$79-\wedge 1$

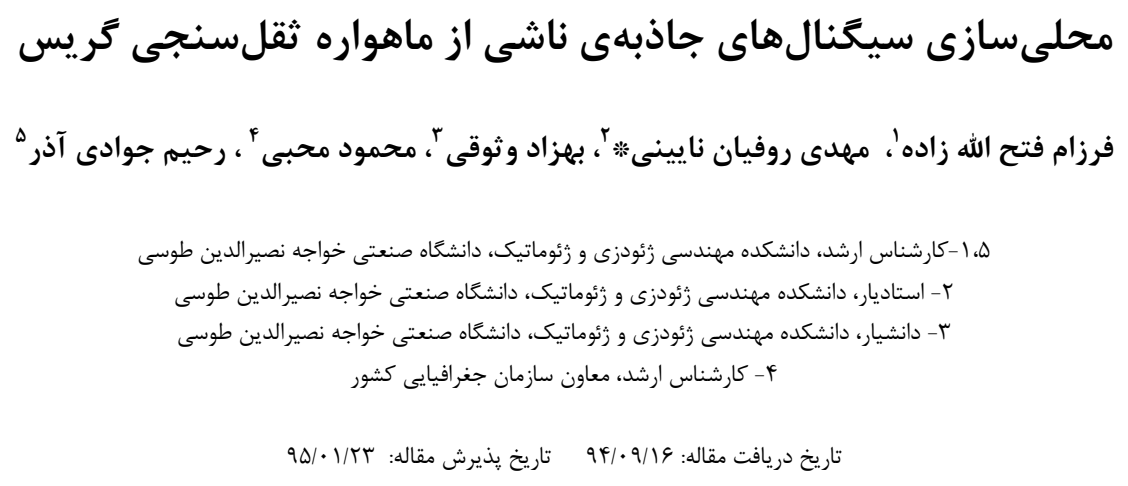

جكيده

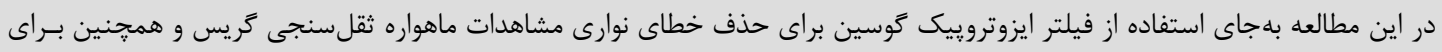

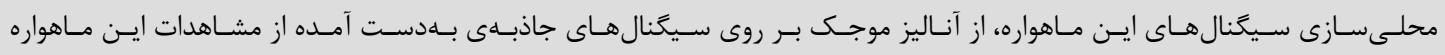

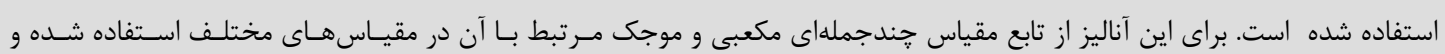

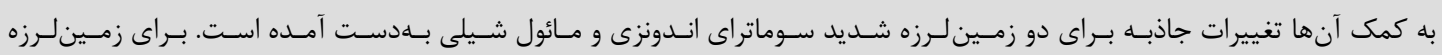

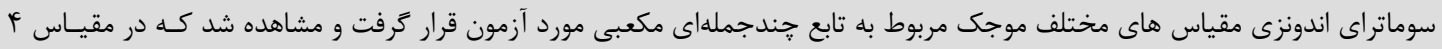

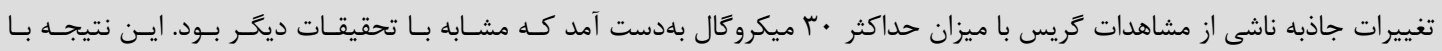

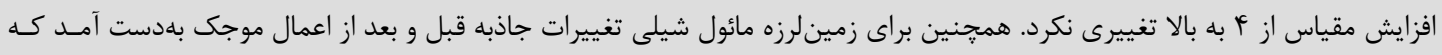

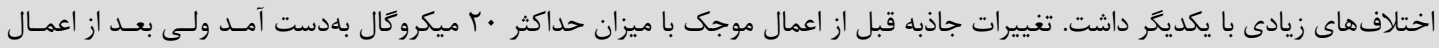

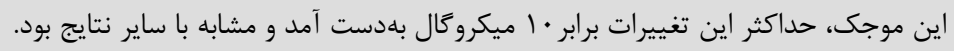

كليدوازهها: آناليز موجك، ماهواره ثقلسنجى تريس، زلزله سوماترا، فيلتر ايزوتروييك توسين

زوزيسنده مكاتبه كننده: مهدى رئوفيان نايينى - آدرس كامل بِستى: تهران، خيابان وليعصر، تقاطع ميرداماد، دانشخاه صنعتى خواجه نصيرالدين طوسى، دانشكده مهندسى زئودزى و تلفن: 


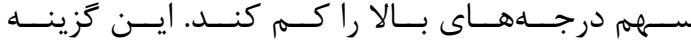

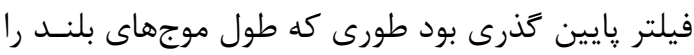

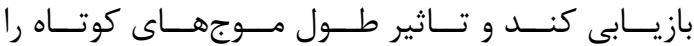

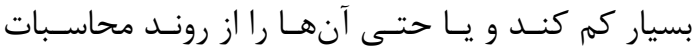

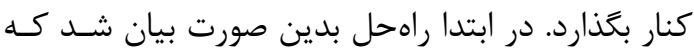

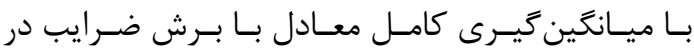
درجه خاصى، ضرائب از آن درجه به بعـد از محاسـبات

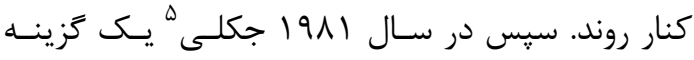
وزندار مستقل از درجه را معرفى كرد. اين تابع وزندار، دارئ

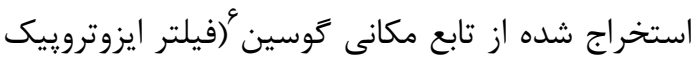

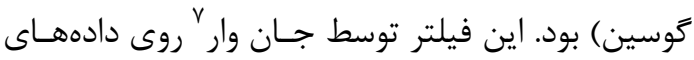

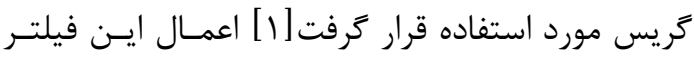

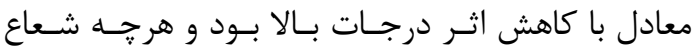
ميانكين خيرى افزايش مى يافت سهم ضرائب درجات بالا

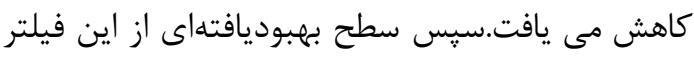

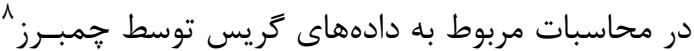

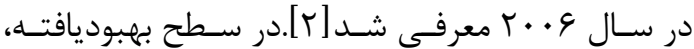

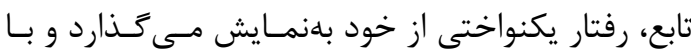

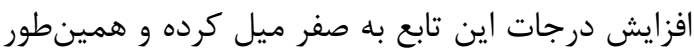

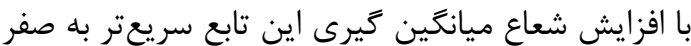

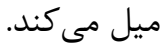

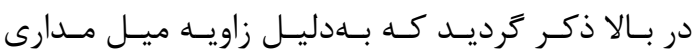

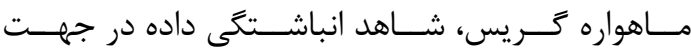

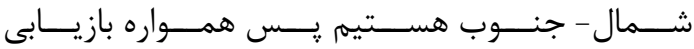

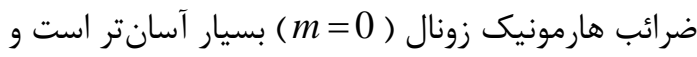

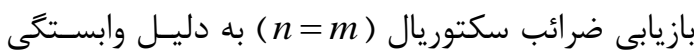

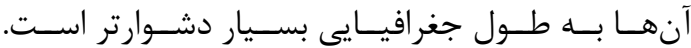

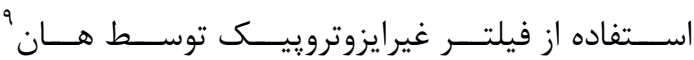
در سال ه • · مطرح شدكه در آن شعاع ميانكين گيرى در فيلتـر كوسـين بـهــــور ديناميـك براسـاس مرتبــهـ

${ }^{5}$ Jekeli

${ }^{6}$ Gausian

${ }^{7} \mathrm{Wahr}$

${ }^{8}$ Chambers

${ }^{9} \mathrm{Han}$
- 1- (- مقدمه

خطاهاى موجود در دادهــاى تَريس شـامل خطاهـاى موجود در ضرائب هارمونيك كروى ميدان جاذبه كريس

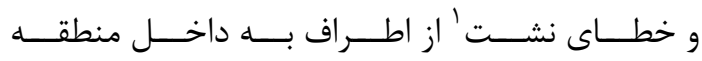

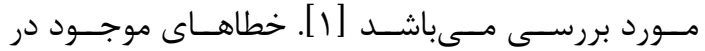
ضرائب استوكس ماهيانه كريس بلعلـت عـواملى خــون

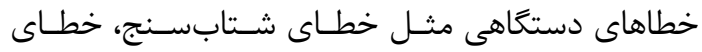

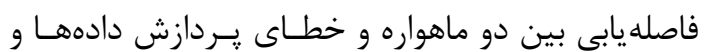

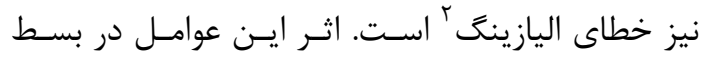

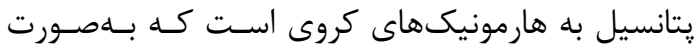
تئورى اين درجها و مرتبهها تا بىنهايت يِيش مىروندا اما عواملى جون دقت دستكاههـاى انـدازهكيــرى و نيـز

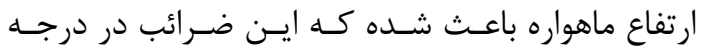

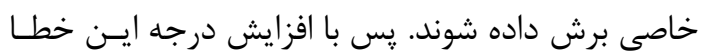

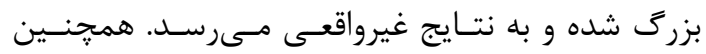

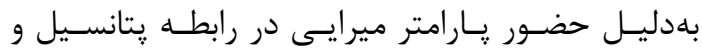

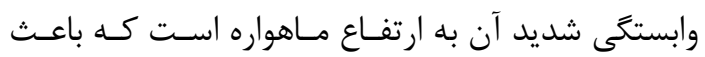
بلوجود آمدن عدم بازيابى صحيح طول موجهاى كوتـاه ميدان ثقل زمين مىشود، يس بايد سهم طولموجهـاى كوتاه يعنى ضرائب بالا در محاسبات كاهش يابد. يكى از مههمترين مسـائل بحرانس در دادههـاى گَريس

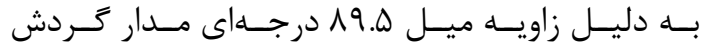

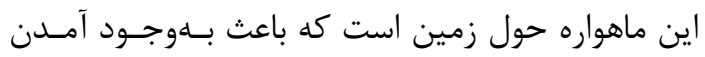

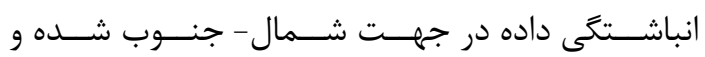
سبب همبستكى " مكانى بين دادهاى كريس مىشـود.

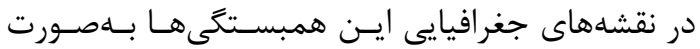

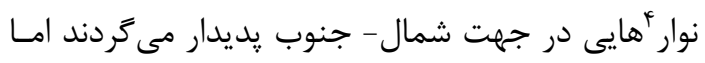

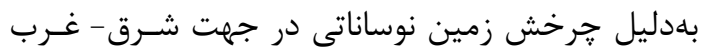

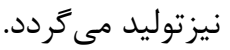

با توجه به موارد فوق نياز به كزينهاى اسـت كـه بتوانـــ

${ }^{1}$ Leakage

${ }^{2}$ Aliasing

${ }^{3}$ Correlation

${ }^{4}$ Stripe 


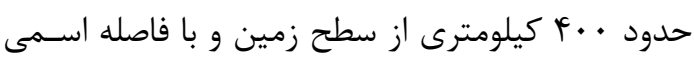

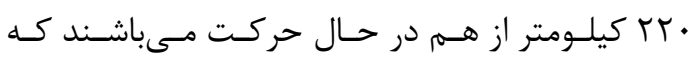
اين فاصله دستخوش تغيير شده و با آناليز اين تغييرات فاصله مىتوان به تغييرات ثقل يىبرد. مدار اين مـاهواره بلهصورت قطبى با زاويه ميل ه.91 درجه مىباشد.

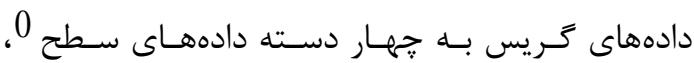

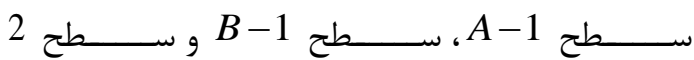

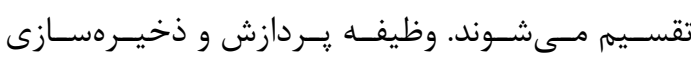

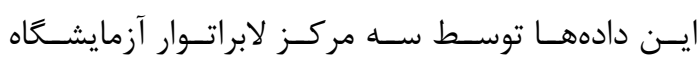

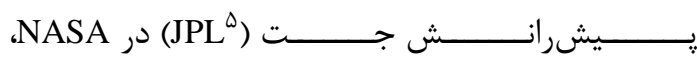

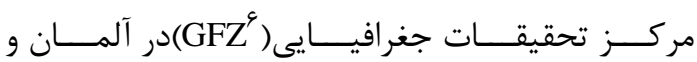

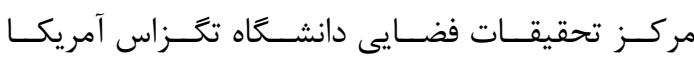

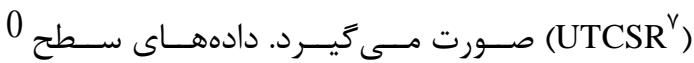

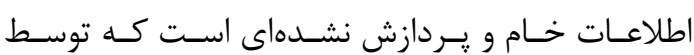

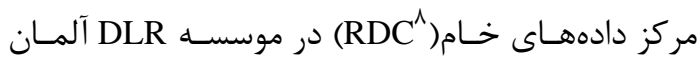

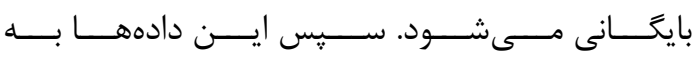

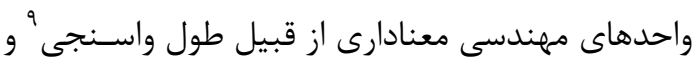

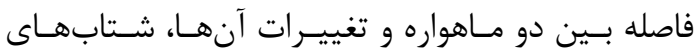

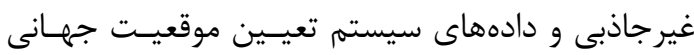

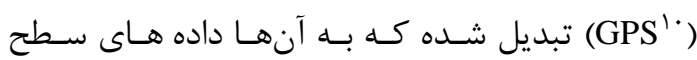

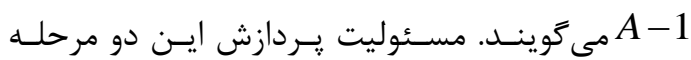

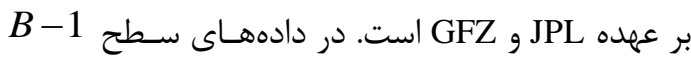

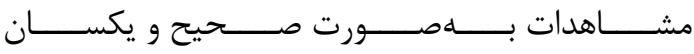

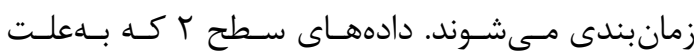

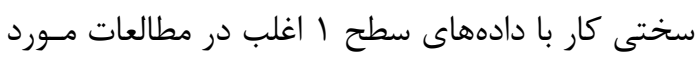

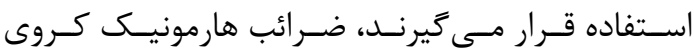

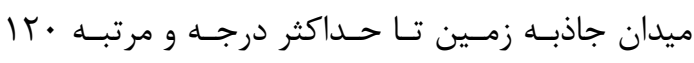

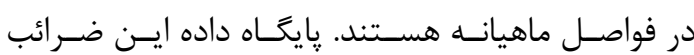

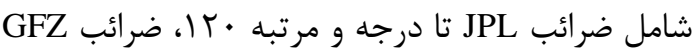

${ }^{5}$ Jet PropulsionLaboratory

${ }^{6}$ Geo Forschungd Zentrum

${ }^{7}$ University of Texas Center for Space Research

${ }^{8}$ Raw Data Center

${ }^{9}$ Calibration

${ }^{10}$ Global Positioning System
ضرائب هارمونيكى تغيير مى كند و اين فيلتر به هردوى درجه و مرتبه هارمونيك هاى كروى وابسته است [بآ]. در اين مقاله بهجـاى اسـتفاده از تـابع محلـى و مكـانى

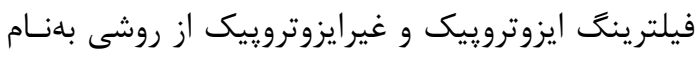

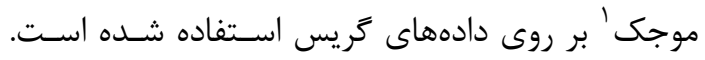

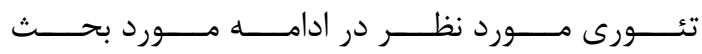

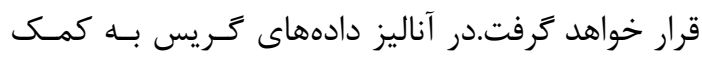

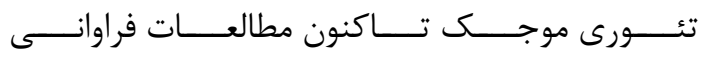
صورت كرفته است. از اين تحقيقات مىتوان به كارهاى

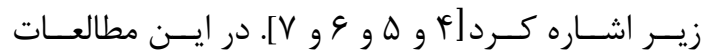

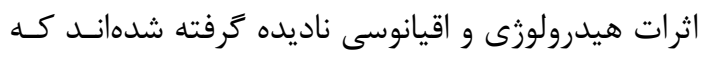

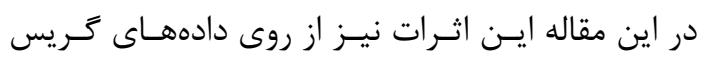
تصحيح شدهاند.

\section{r- ماهواره ثقلسنجى كريس و دادههاى آن}

براى بررسى ميـدان ثقــل زمسين در بـازههـاى زمـانى

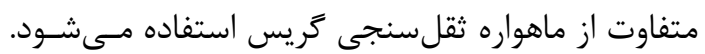

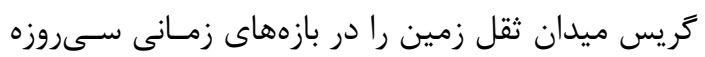

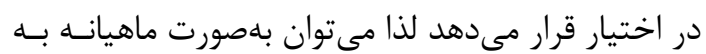

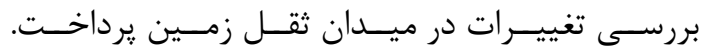

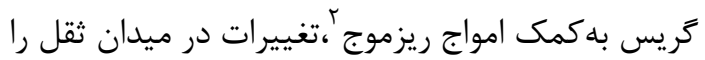
بر اساس اندازهيرىهاى خود كه بر پايه تغييرات جـرم

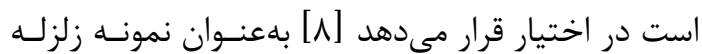

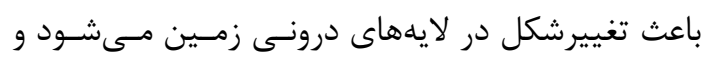

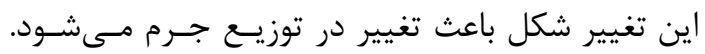

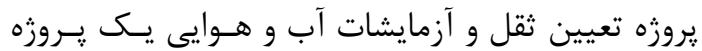

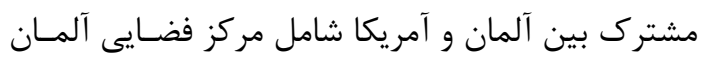

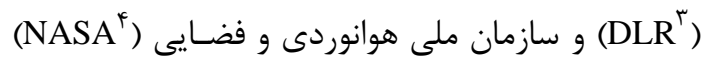

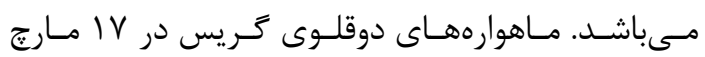

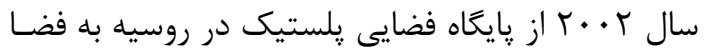

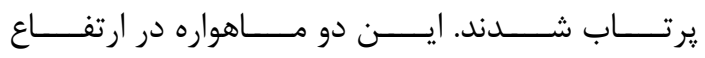

\section{${ }^{1}$ Wavelet}

${ }^{2}$ Microwave

${ }^{3}$ Deutsche Zentrum fur Luftund Raumfahrt

${ }^{4}$ NationalAeronautics and SpaceAdministration 
r- استفاده از موجك كروى بهعنوان يك فيلتـــ

محلى

هارمونيكهاى كروى براى توابعى كه در خـارج از كـره در معادله لإيلاس صدق مى كنند كلاسى از توابـع پايسها

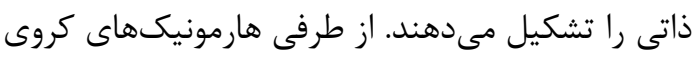

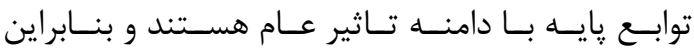

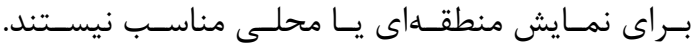

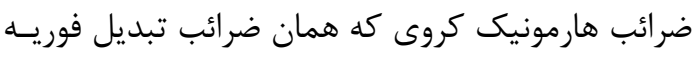

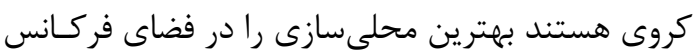
فراهم كرده ولى اطلاعات مكانى نمى دهند لذا از موجك

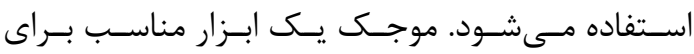
فيلتر كردن سيخنالهاى محلى و بررسى اثرات تغييرات

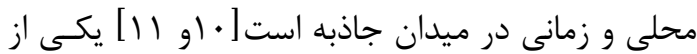

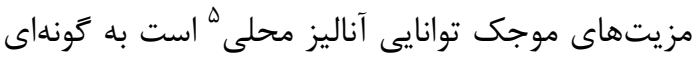

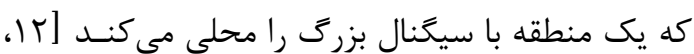

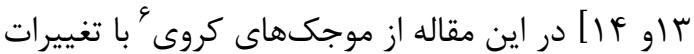
زمانى و محلى ميدان ثقل مشاهده شده توسط گَريس

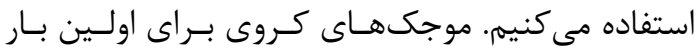

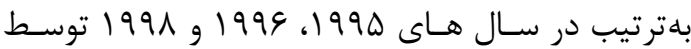

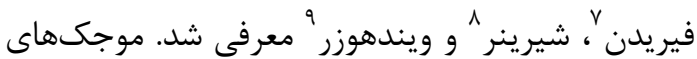

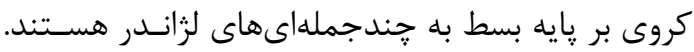

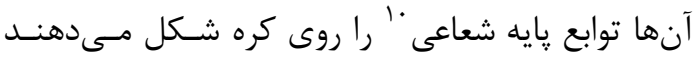
بلهورتى كه فقط بستخى به فاصـله كـروى بــين مركـز موجك و نقطه مورد ارزيابى دارند.

در اينجا از نمادهاى فريدن و همكاران در سـال 1991

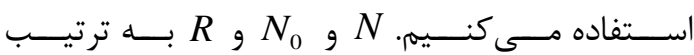
مجموعـههــاى اعـداد صـحيح مثبــت، اعـداد صـحيح غيرمنفى و اعداد حقيقى مسىباشـند. از نمـايش براى نمـايش عناصـر سـهبعـدى فضـاى اقليدسىى

\footnotetext{
${ }^{5}$ Local Analysis

${ }^{6}$ Spherical Wavelet

${ }^{7}$ Freeden

${ }^{8}$ Schreiner

${ }^{9}$ Windheuser

${ }^{10}$ Radial Base Functions
}

تا درجه و مرتبه • و و ضرائبUTCSR تا درجه و مرتبـه

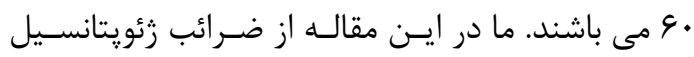

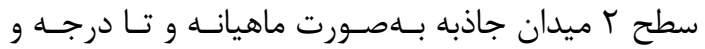

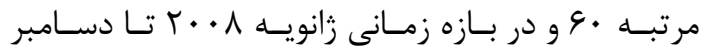

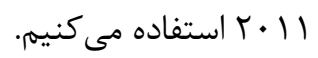

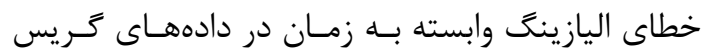

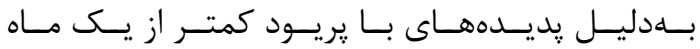

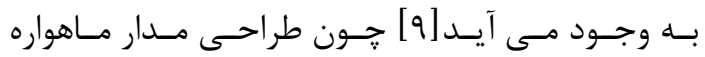
به گَنهاى است كه در طول يك ماه از مسيرهاى خاصى عبـور كنــد يـس در طـول يـك مــاه كـل كـــه زمـين يوشش داده نمىشود يس برخى : بديدهها كه دورهآنها

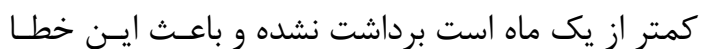

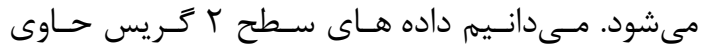

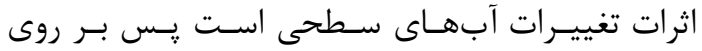

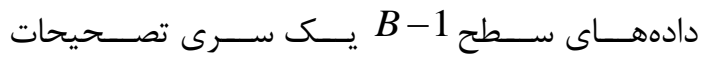

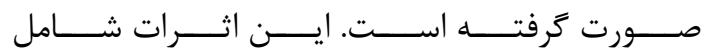
اثرات جزرومد زمين، جزرومد قطبسى، فشـار اتمسـفر و جزرومد اقيانوسى مىباشد. اثرات حاصـل از جـزر و مــد

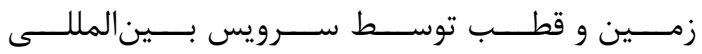

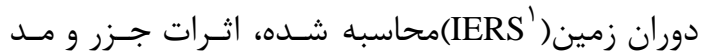
اقيانوسى توسط مدل اقيانوسـى المـان محسـدود ؟ +..

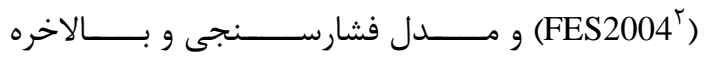

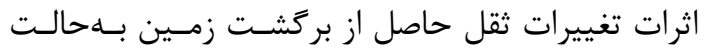
قبل از عصر يخبندان بهعلت آب شدن يـخَهـاى قطبـى

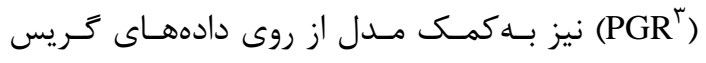

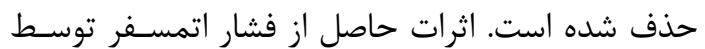

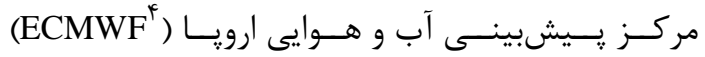
با استفاده از يروفيلهاى فشار اتمسفر در نقاط مختلـف ئف

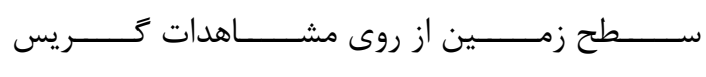
تصحيح شده است.

${ }^{1}$ International Earth Rotation Service

${ }^{2}$ FiniteElementSolution 2004

${ }^{3}$ Post Glacial Rebound

${ }^{4}$ European Center of Medium-range Weather Forecast 
Error! Bookmark not

(9) رابطه

$$
0 \leq\left(\hat{\phi}_{J}(n)\right)^{2} \leq\left(\hat{\phi}_{J^{\prime}}(n)\right)^{2} \text { defined. }
$$

(ب) براى تمام

Error! Bookmark

(V) رابطه

$$
\lim _{J \rightarrow \infty}\left(\hat{\phi}_{J}(n)\right)^{2}=1 \text { not defined. }
$$

براى تمام ثوابت $\left\{\hat{\phi}_{J}(n)\right\}_{n \in N_{0}}$ دنبابع $J \in N_{0}$

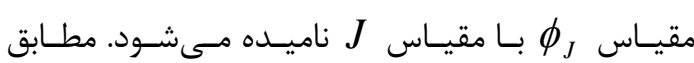

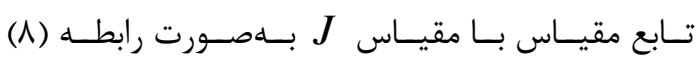
تعريف مى شود:

Error! Bookmark not defined.

رابطه (1)

$$
\phi_{J}(\xi, \eta)=\sum_{n=0}^{\infty} \hat{\phi}_{J}(\mathrm{n}) \frac{2 n+1}{4 \pi} P_{n}(\xi . \eta)
$$

حال به بررسى موجكهاى مرتبط با توابع مقياس $\left\{\left\{\hat{\Psi}_{J}(n)\right\}_{n \in N_{0}}\right\}_{J \in N_{0}} \quad$ مى يردازيم. خانوادئ و بكلةترتيب عملكرهاى يحانه $\left\{\left\{\hat{\tilde{\Psi}}_{J}(n)\right\}_{n \in N_{0}}\right\}_{J \in N_{0}}$

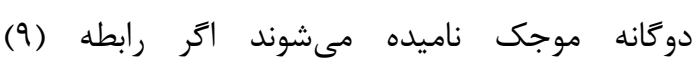
برقرار باشد: - بوانه

رابطه(9) (9) $\hat{\tilde{\Psi}}_{J}(n) \hat{\Psi}_{J}(n)=\left(\hat{\phi}_{J+1}(n)\right)^{2}-\left(\hat{\phi}_{J}(n)\right)^{2}$ موجك يكانه و دوكانه نيز همانند تابع مقياس بلهصورت

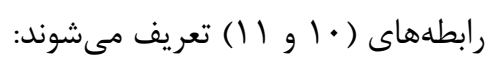

رابطه(• (1) Eookmark not defined

$$
\tilde{\Psi}_{J}(\xi, \eta)=\sum_{n=0}^{\infty} \hat{\tilde{\Psi}}_{J}(\mathrm{n}) \frac{2 n+1}{4 \pi} P_{n}(\xi . \eta)
$$

رابطه (1) (1) Bookmark not defined

$$
\begin{array}{r}
\Psi_{J}(\xi, \eta)=\sum_{n=0}^{\infty} \hat{\Psi}_{J}(\mathrm{n}) \\
\text { فرض مى كنيم كه: }
\end{array}
$$

$$
\begin{aligned}
& \text { اسـتفاده مسى كنـيه. ضـرب داخلـى و نـرم' بـهـترتيـب } \\
& \text { بdصورت رابطههاى ( ا و r) تعريف مى شوند: } \\
& x . y=\sum_{i=1}^{3} x_{i} y_{i} \\
& \text { رابطه (1) } \\
& |x|=\sqrt{x \cdot x} \\
& \text { رابطه (T) } \\
& F=\sum_{n=0}^{\infty} \sum_{k=-n}^{n} F_{n, k} Y_{n, k} \quad \text { (T) } \\
& F_{n, k}=\int_{\Omega} F(\eta) \mathrm{Y}_{n, k}(\eta) \mathrm{dS}(\eta) \quad \text { (أبطه }
\end{aligned}
$$
r-1 - - توابع مقياس

تان

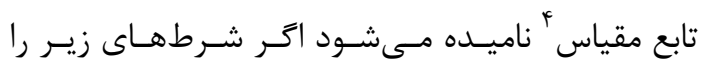

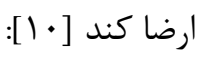
(1) (براى تمام

Error!

رابطه (b)

$$
\begin{aligned}
& \left(\hat{\phi}_{J}(0)\right)^{2}=1 \text { Bookmark not defined. } \\
& \text { (r) براى تمام }
\end{aligned}
$$

${ }^{1}$ Norm

${ }^{2}$ Hilbert Space

${ }^{3}$ Orthonormal

${ }^{4}$ Scale Function 
شكل ا: تابع مقياس جندجملهاى مكعبى در مقياس

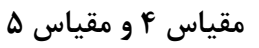

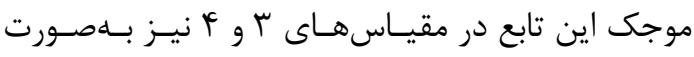
شكل (r) مشخص است:

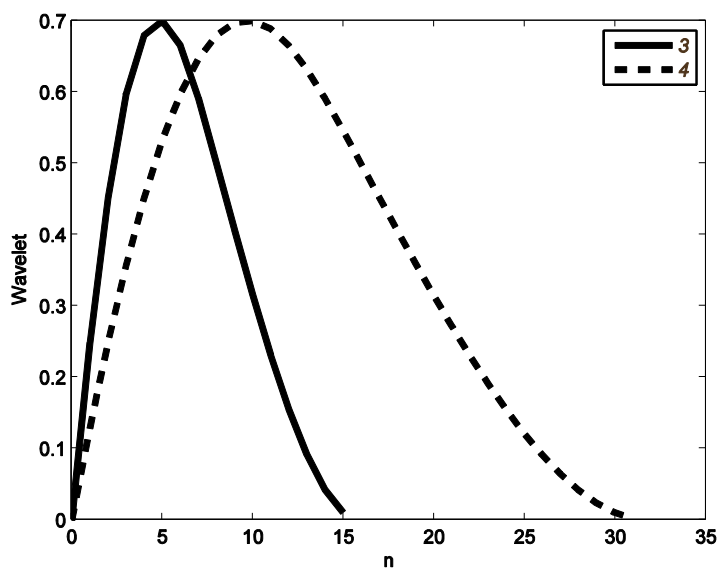

شكل r:موجك جندجملهاى مكعبى در مقياس سا، مقياس

همجنين اين موجك در فواصل كروى مختلف بهصورت شكل (ץ) به نمايش در آمده است:
Error! Bookmark not defined. (IT) (IT)

$$
\tilde{\Psi}_{J}(n)=\Psi_{J}(n), J \in N_{0}, n \in N
$$

يس رابطه موجك و تابع مقياس بهصورت رابطه (II)

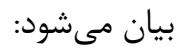

رابطه (ITror! Bookmark not defined. (IT)

$$
\hat{\Psi}_{J}(n)=\sqrt{\left(\hat{\phi}_{J+1}(n)\right)^{2}-\left(\hat{\phi}_{J}(n)\right)^{2}}
$$

رابطه (If)

$$
\hat{\phi}_{J}(n)= \begin{cases}\left(1-2^{-J} n\right)^{2}\left(1+2^{-J+1} n\right) & \text { for } n \in\left[0,2^{J}\right) \\ 0 & \text { for } n \in\left[2^{J}, \infty\right)\end{cases}
$$

همانطور كه مشخص است ايسن توابـع هـر سـه شـرط

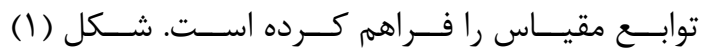
تابع مقياس جندجملهاى مكعبى را در مقياسهـاى بـ و و

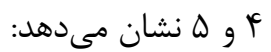
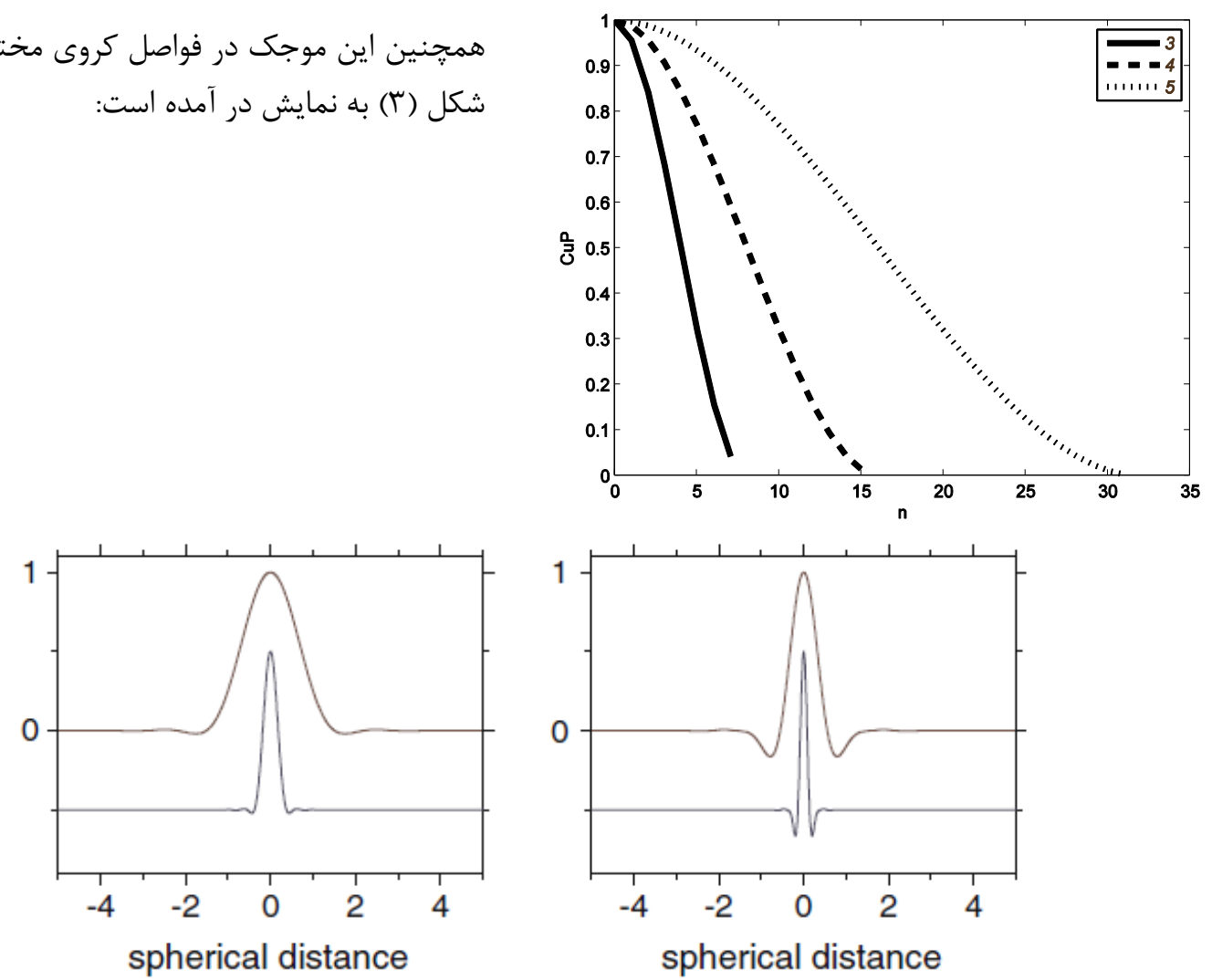

$\mathrm{j}=8$ 
سوندا و برمه است. وجود جنين يِيجيدگى ساختارى در

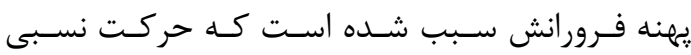

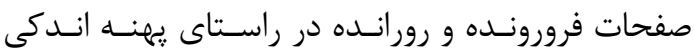

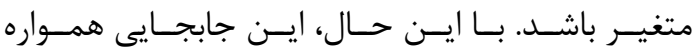

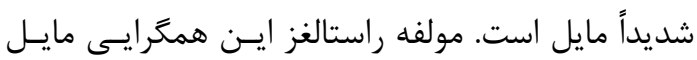

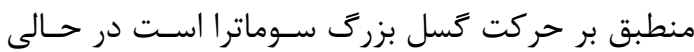

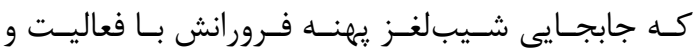
جابجايى گسل بزرى سوماترا تامين مىشود. مكاتراست

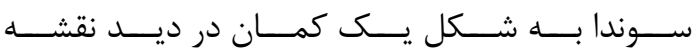
مشاهده مى شود. شيب اين گسل متغير است به طورى

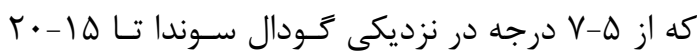

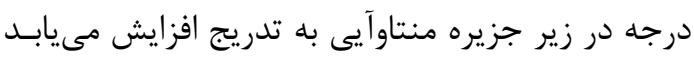

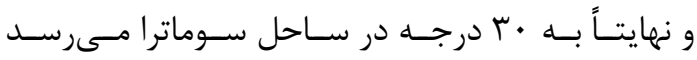

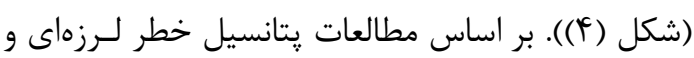

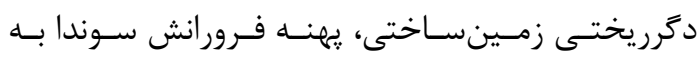

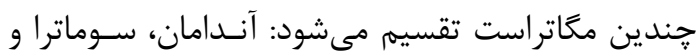

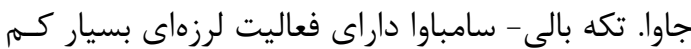

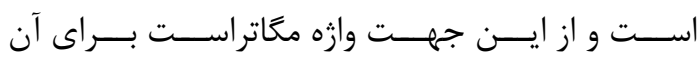

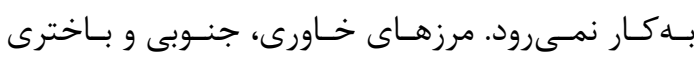

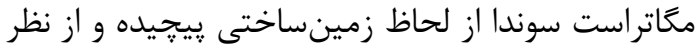

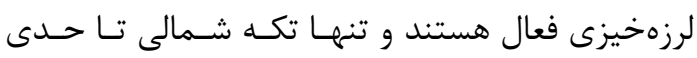

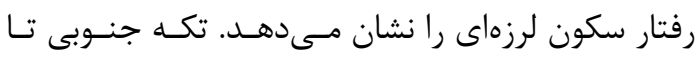

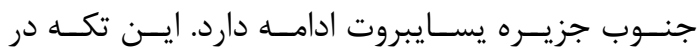

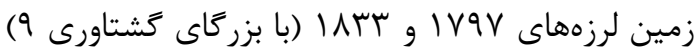

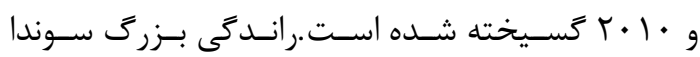
ماهيتاً سبب رخداد زمين لرزه هاى بزرك مى شى شود.

\section{F - مناطق مورد مطالعه و نتايج عددى}

زلزله سوماترا با قدرت / 9/ ريشـتر كـه در ع دسـامبر

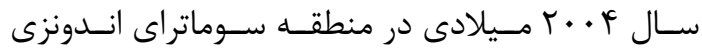

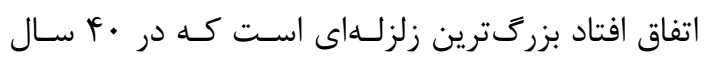
اخير ثبت شده است. اين زلزله امواج سونامى توليد كرد

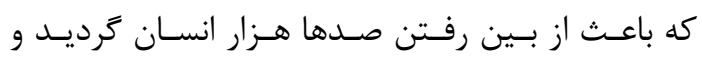

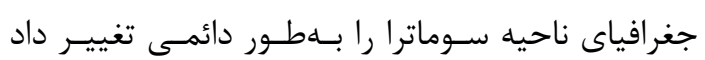
بهَّونهاى كه براى برخى جزايـر آن تـا حـدود • ب متــر

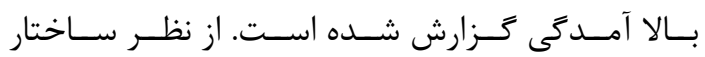

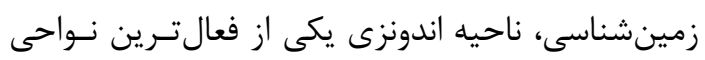

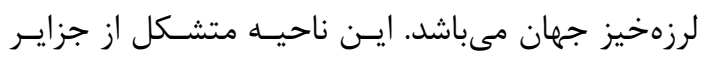

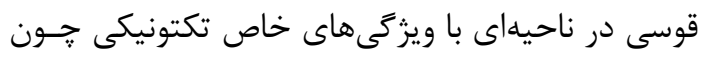

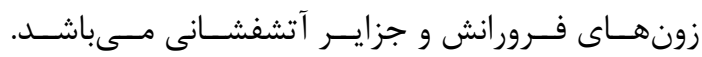
در اين ناحيه صفحات متعددى همجيون صفحه اونه اوراسيا،

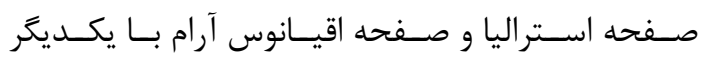

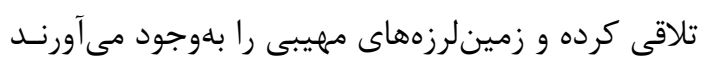
جان همكَرايى اين صفحات در مجاورت سوماترا شـديدا

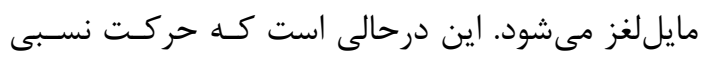

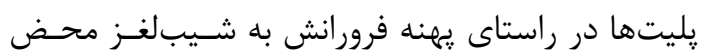

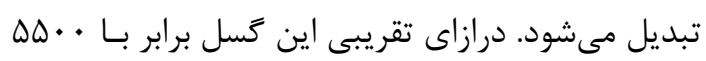

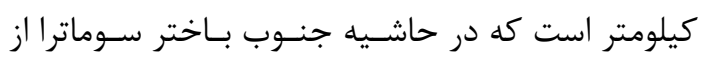

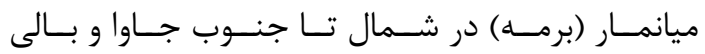

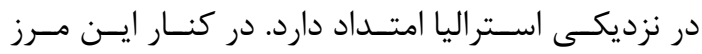

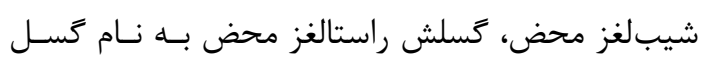

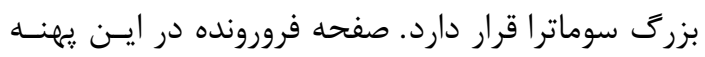

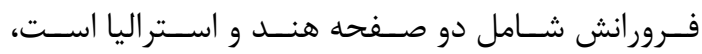
همجنين صفحه رورانده نيز خود شامل دو صفحه فرعى 


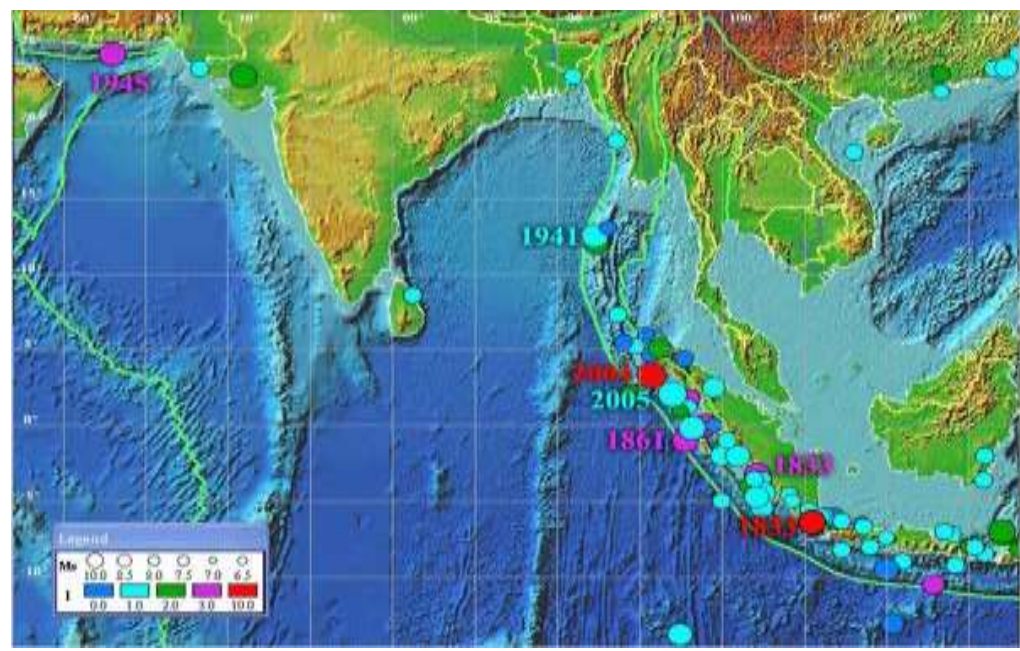

][USGS شكل †:منطقه فرورانش سوماتراى اندونزى

$$
\begin{aligned}
& \frac{R}{G M} \Psi_{J} * \Delta V_{i j(t, x)}= \\
& \sqrt{4 \pi} \sum_{n=2}^{60} \sum_{m=-n}^{n} \Delta V_{i j}(t) \hat{\Psi}_{J}(n) Y_{n, m} \quad(\mid \Delta) \text { (ابط }
\end{aligned}
$$

كـه در آن GM تغييرات جاذبه بهدست آمده از كريس مىباشد.

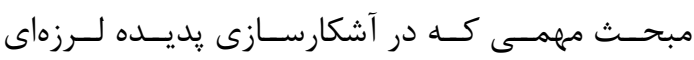

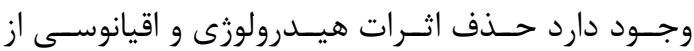

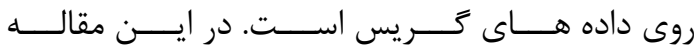

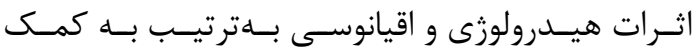

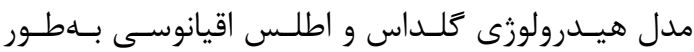
همزمان از روى دادههاى گريس حذف شدهاند. تئورى و

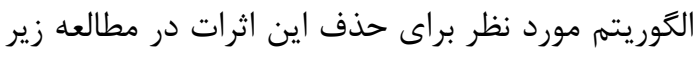

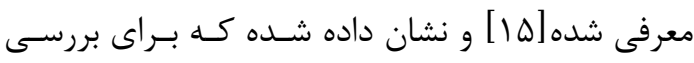
جابجايىهاى ناشى از زلزله تصحيح ايـن اثـرات الزامسى

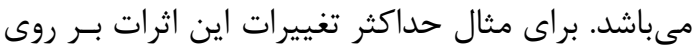
جاذبه در منطقه سوماتراى اندونزى برابر • إ ميكروخـال بهدست آمد [ها] كه نشان داد حذف اين اثرات بـراى

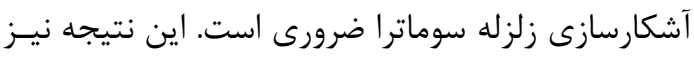

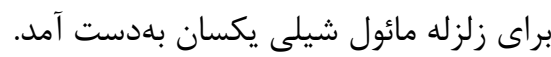

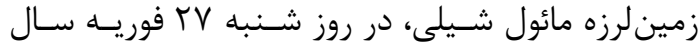

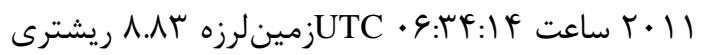

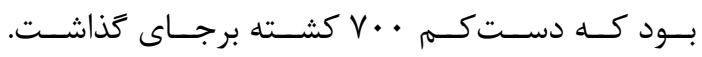

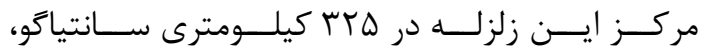

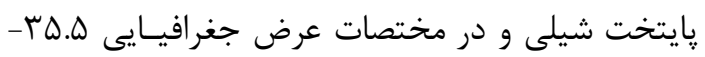

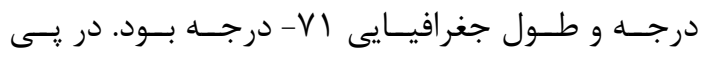
اين زمينلرزه در باه كشور اعـلام خطـر ســونامى شـد.

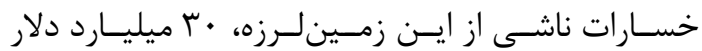

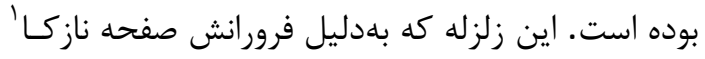

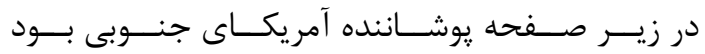
ششمين زلزله بزرى در وقايع ثبت شده است. اين زلزله

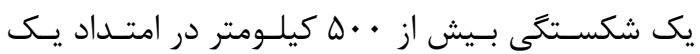

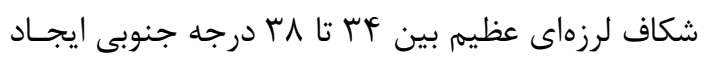

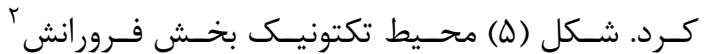

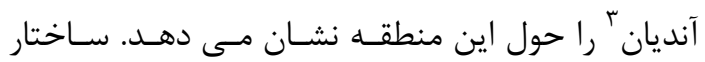
زمينشناسى ايـن منطقـهـ نسـبت بـهـ منطقـهـ سـوماترا

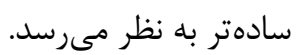
در ارتباط با كريس مىتوان موجك جندجملهاى كروى را بهصورت زير استفاده كرد [11]:

${ }^{1} \mathrm{Nazca}$

${ }^{2}$ Subduction

${ }^{3}$ Andean 


\section{شكل ه:منطقه تكتونيك بخش فرورانش آنديان شيلى ][USGS}

در ايـن آزمــون ابتـدا بــراى زلزلـهـ سـوماتراى انـدونزى

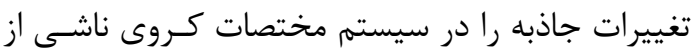

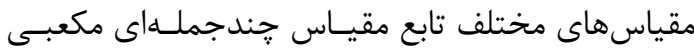

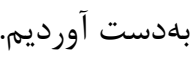

در مقياسهاى r و ب مشاهده شدهاسـت كـه تغييـرات

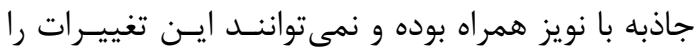
به خوبى نشان دهند. در مقياسهاى

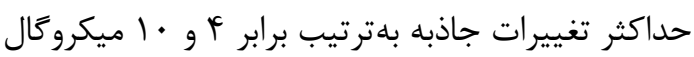

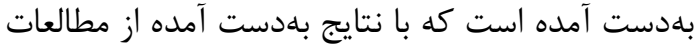
قبلى همخوانى ندارد [1 [1].

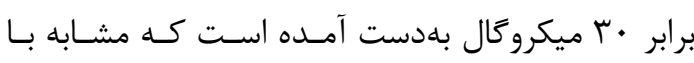

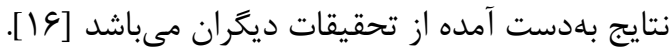

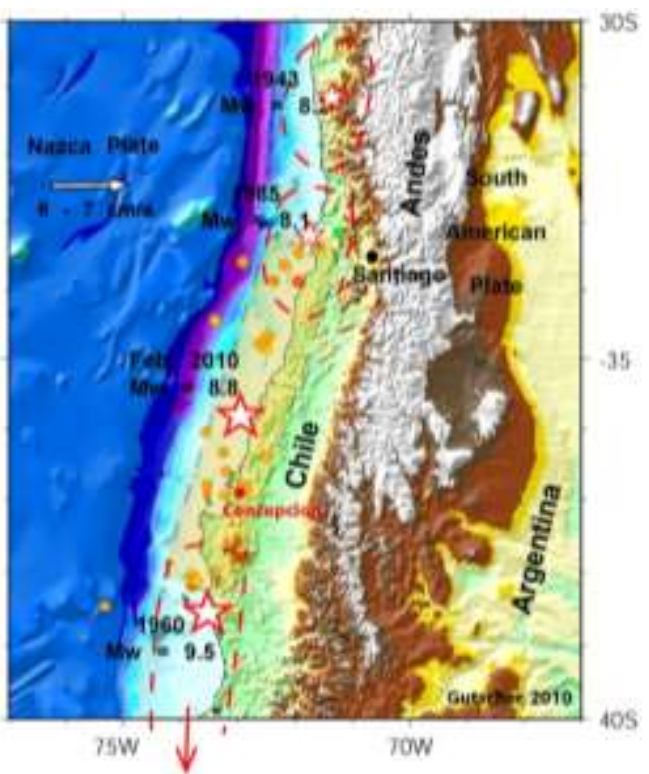

همانطور كه از شـكلهـاى (؟، لاو ^) مشـخص اسـت تغييرات جاذبه در مقياس مقادير معتبر بلهدست آمده است. حداكثر ايـن تغييـرات
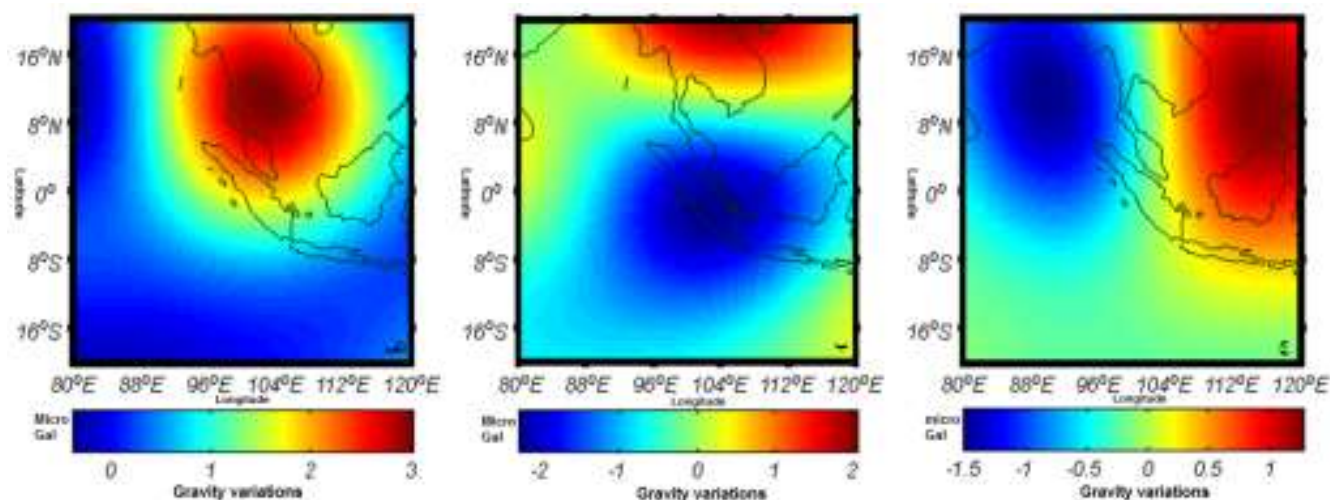

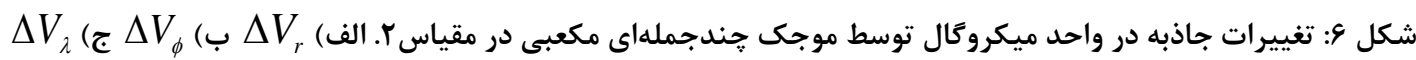
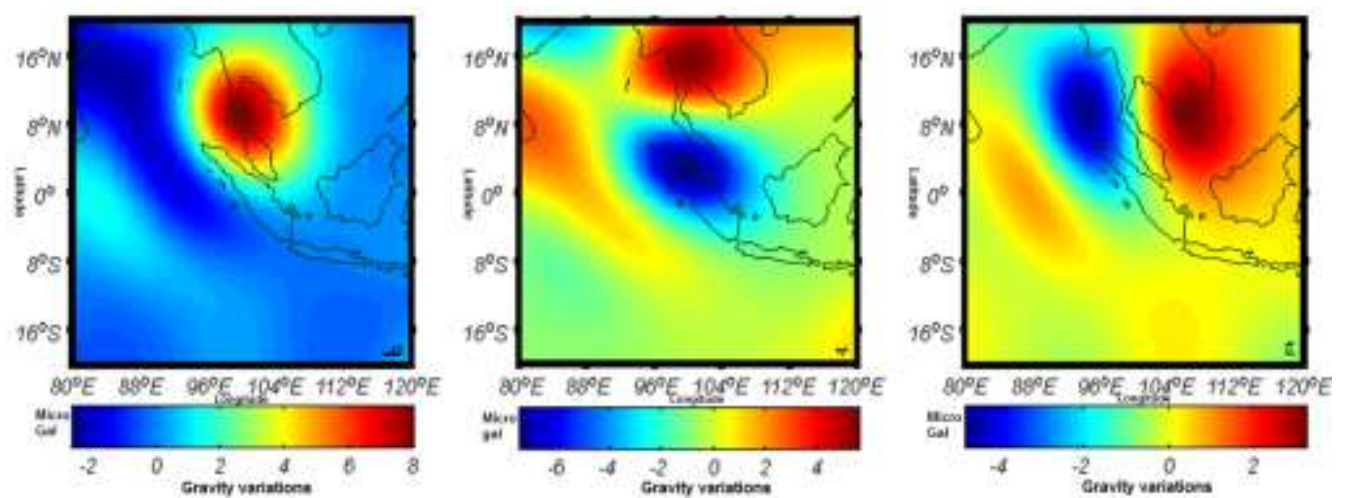

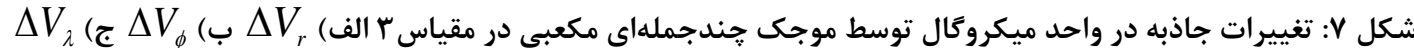



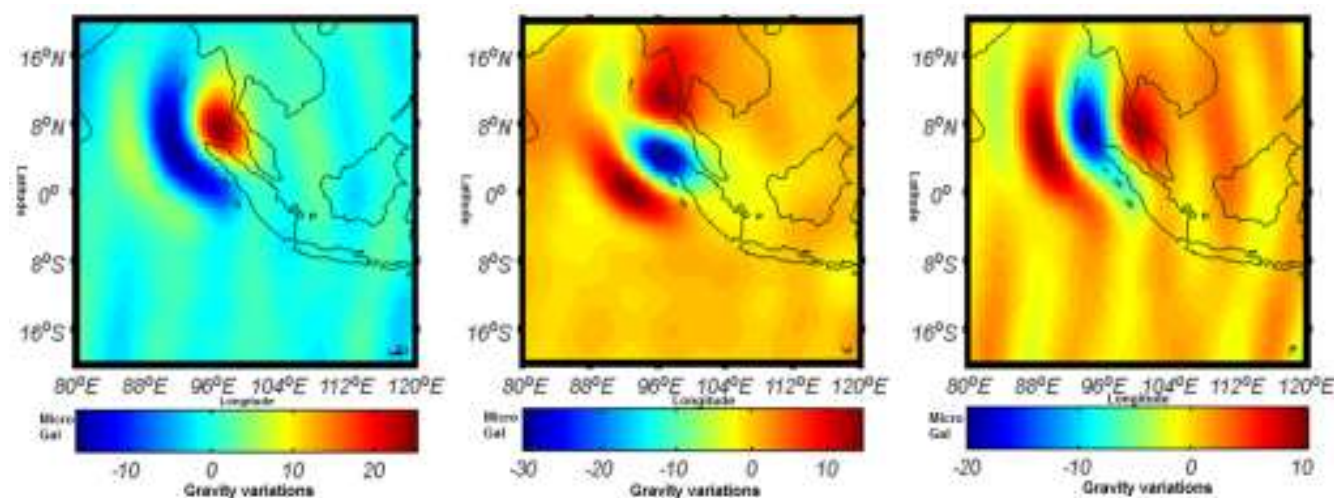

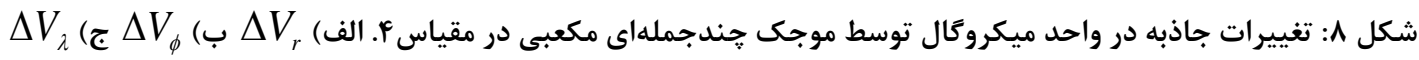

است. طـول و عـرض گسـل در ايسن منطقـه بـوده كـهـ

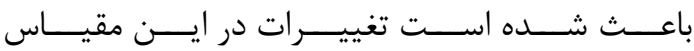
به نمايش در آيند.

اين نتيجه در مطالعات ديخر نيز مورد ارزيابى و مطالعـه

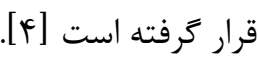

علاوهبر اين براى زلزله مائول شيلى تغييـرات جاذبـه در

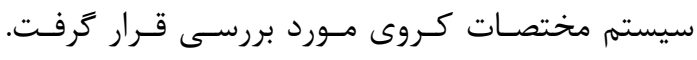

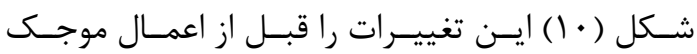

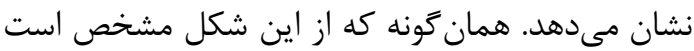
اين تغييرات بهصورت نويز بهدست آمده است كه همان

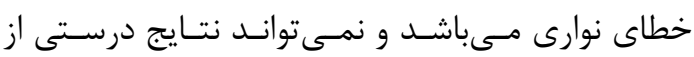

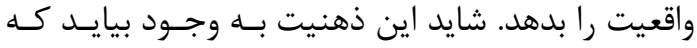
با توجه به اينكه گسل آنديس در جهت شمال و و جنوب دهن

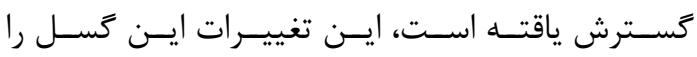
نشان دهد ولى در منطقه آنديسيك صفحه انبسـاطى و يك صفحه انقباضـى بيشـتر نبـوده كـه در شـكل زيـر

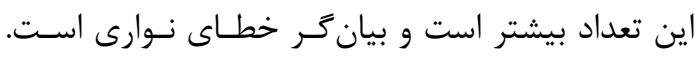

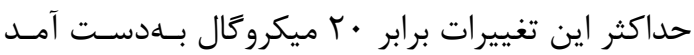

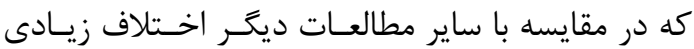
[lv]د
همجنين تغييرات جاذبه توسـط موجـى جندجملــاى مكعبى در مقياس هاى ه و و بهدست آمد. همانطور كه در شكل(9) مشخص است از مقياس f أ به بعد تغييـرات

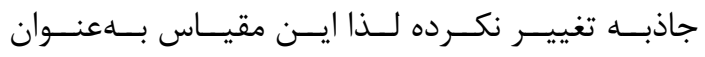
مقياس مورد نظر انتخاب گرديد.

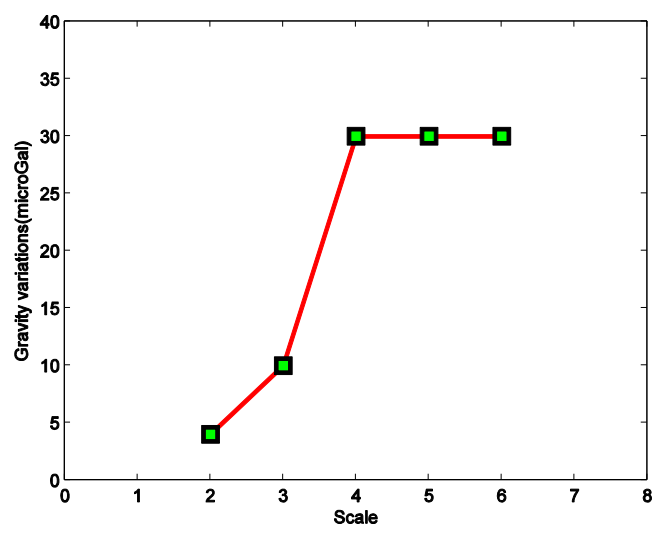

شكل 9: تغييرات جاذبه در واحد ميكروكال توسط موجك

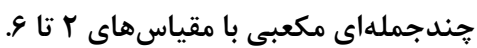

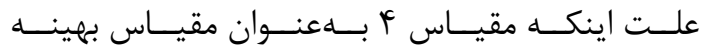
انتخاب شده اسـت ايسن اسـت كـهـ در منطقـهـ سـوماترا

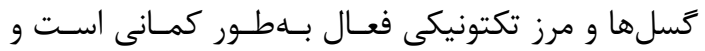
در اين مقياس، اين مرز كمـانى بـهـ خـوبى بـهـ نمـايش

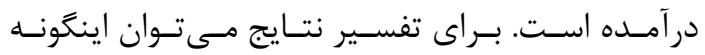

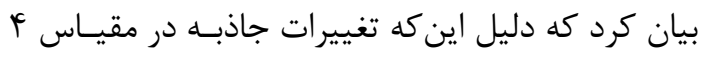
به خوبى قابل نمايش بوده و از آن مقياس به بعد ديخـر

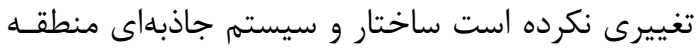



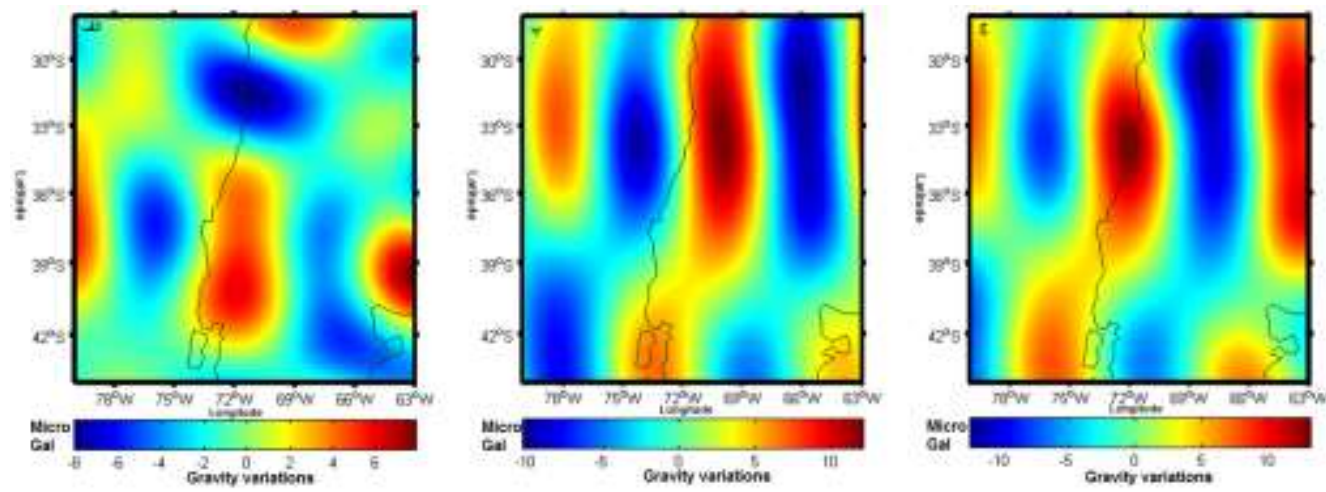

شكل •|: تغييرات جاذبه در ماه مارج •(r.1 قبل از اعمال موجك (در واحد ميكروكال). الف) در جهت شعاع. ب)در جهت عرض

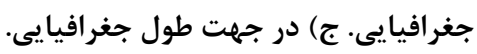

نويزى بهدست آمدهاند (شامل منـاطق انقباضى يعنسى

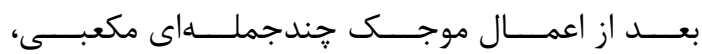

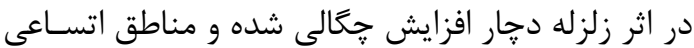

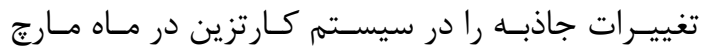

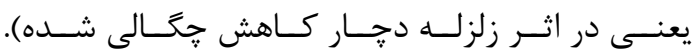

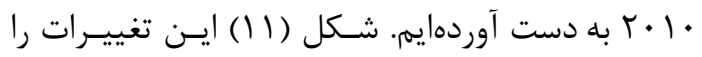

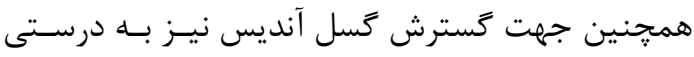

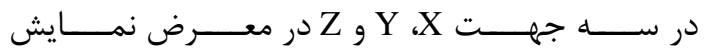

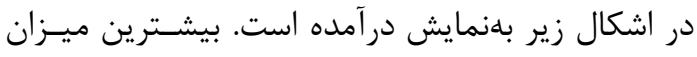

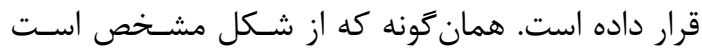

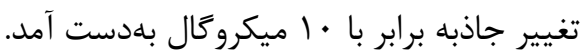

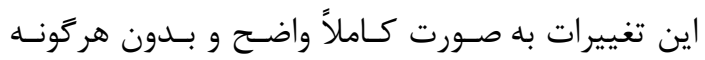
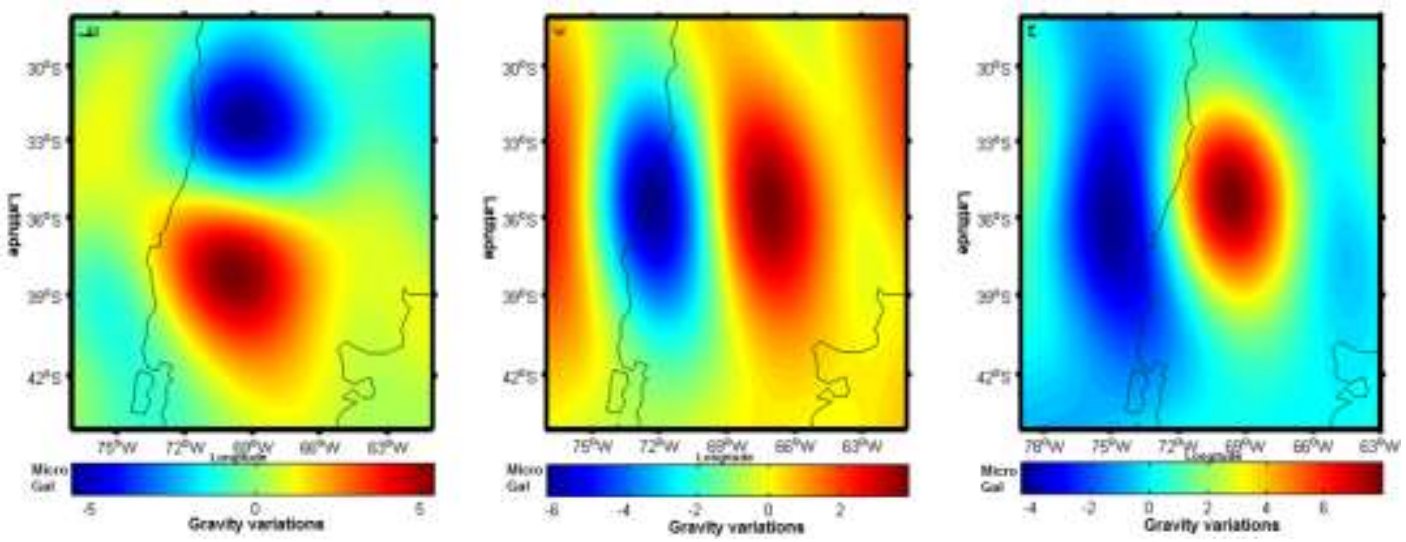

شكل |ا: تغييرات جاذبه در ماه مارج •ا+r بعد از اعمال موجك (در واحد ميكروكال). الف) در جهت Xب)در جهت Y ج) در جهت

بازيابى كند و تاثير طول موجهـاى كوتـاه را بسـيار كـم

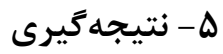

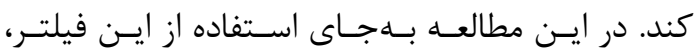
راهحل يِيشنهادى استفاده از تابع موجك است. موجـك ابـزارى مناسـب بـراى محلـى كـردن سـيكنال بــوده و

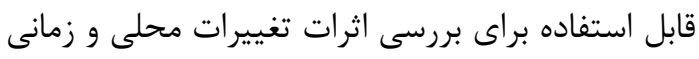
در ميدان جاذبـهـ زمسين اسـتـبراى ايـن آنـاليز از تـابع مقياس جندجملهاى مكعبى و موجك مـرتبط بـا آن در

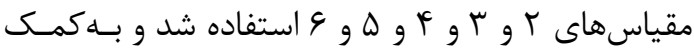

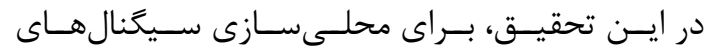

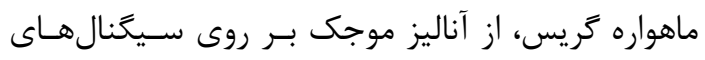

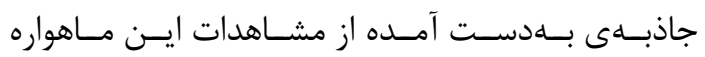

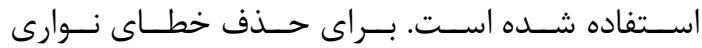

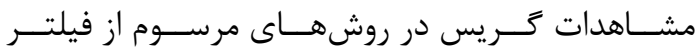

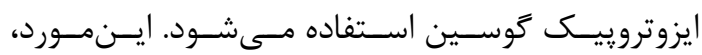

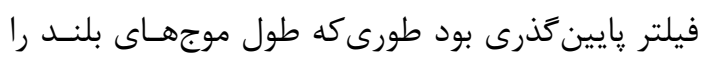


همجنين براى زمينلرزه مائول شـيلى تغييـرات جاذبـهـ

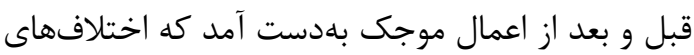

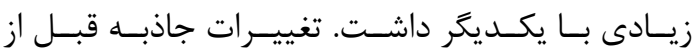

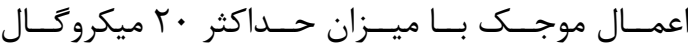

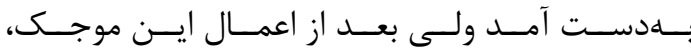

حداكثر اين تغييرات برابر • ل ميكروگال بهدست آمـد و

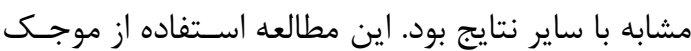

را بهجــاى اسـتفاده از فيلتـر كوسـين بـراى مشـاهدات

كريس زيشنهاد مى ندهد.

[1] J. Wahr, M. Molenaar, F. Bryan, "Time variability of the Earth's gravity field: Hydrological and oceanic effects and their possible detection using GRACE", J. Geophys. Res., 103, 30,229-32,205, 1998.

[2] D. P. Chambers, "Evaluation of new GRACE time-variable gravity data over the ocean", Geophys. Res. Lett., 33, L17603, 2006.

[3] S. C. Han, C. K. Shum, C. Jekeli, C. Y.Kuo, C.Wilson, K.Seo, "Non isotropic filtering of GRACE temporal gravity for geophysical signal enhancement" Geophys. J. Int., 163, 18-25, 2005.

[4] M. Schmidt, M. Fengler, T. MayerGur, A. Eicker, J. Kusche, L. Sanchez, S. C. Han, "Regional gravity modeling in terms of spherical base functions", J. Geodesy 81,17-38, 2007.

[5] M. Schmidt, S.-C. Han, J. Kusche, L. Sánchez, C.K. Shum,"Regional highresolution spatiotemporal gravity modeling from GRACE data using spherical wavelets", Geophys. Res. Lett., 33, L08403, 2006.

[6] M. Schmidt, J. Kusche, J. van Loon, C. K. Shum, S.-C. Han, O. Fabert, "Multiresolution representation of regional gravity data, in Gravity, Geoid and Space Missions", Int. Assoc. of Geod. Symp. Ser., vol. 129,edited by C. Jekeli, L. Bastos, and
آنها تغييرات جاذبه براى دو زمينلرزه شديد سوماتراى

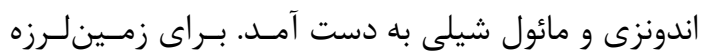

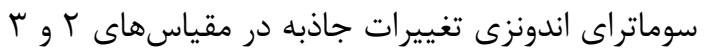
موجك مربوط به تابع جندجملـهاى مكعبـى بـــترتيـب

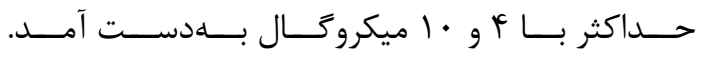
همجنين مشاهده شد كه در مقياس f إنغييرات جاذبـه

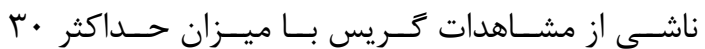
ميكرو Fال بهدست آمد كه مشابه با تحقيقات ديخر بـود. اين نتيجه با افزايش مقياس از f به بالا تغييـرى نكـرد.

\section{مراجع}

J. Fernandes, 167-172, 2005.

[7] I. Panet, A. Chambodut, M. Diament,M. Holschneider, O. Jamet, "New insights on intraplate volcanism in French Polynesia from wavelet analysis of GRACE, CHAMP, and sea surface data”, J. Geophys. Res., 111, B09403, 2006.

[8] B. D. Tapley, S. Bettadpur, M. Watkins, C. Reigber, "The Gravity Recovery and Climate Experiment: Mission overview and early results", Geophys. Res. Lett., 31, L09607, 2004.

[9] H. Dobslaw, M. Thomas, “Considering ECMWF forecast data for GRACE dealiasing",Proc. Joint CHAMP / GRACEScienceTeam Meeting 2004, 2004.

[10] W. Freeden, T. Gervens, M. Schreiner, "Constructive Approximation on the Sphere (With Applications to Geomathematics)", Oxford SciPubl, Clarendon, 1998.

[11] M. J. Fengler, W. Freeden, A. Kohlhaas, V. Michel, T. Peters, "Wavelet modelling of regional and temporal variations of the Earth's gravitational potential observed by GRACE”, J. Geodesy 81,5-15, 2006.

[12]A. C. Kohlhaas, "MultiscaleModelling of Temporal and SpatialVariations in theEarth'sGravityPotentialObservedby

GRACE", Diploma-thesis, Univ of Kaiserslautern, Dept of Mathematics, GeomathematicsGroup, 2005. 
[13][13[ I. Panet, V. Mikhailov, M. Diament, F. Pollitz, G. King, O. de Viron, M. Holschneider, R. Biancale, J. M. Lemoine, "Coseismic and postseismic signatures of the Sumatra December 2004 and March 2005 earthquakes in GRACE satellite gravity", Geophys. J. Int., 171(1), 177-190, 2007.

[14]I. Panet, F. Pollitz, V. Mikhailov, M. Diament, P. Banerjee, K. Grijalva, "Upper mantle rheology from GRACE and GPS postseismic deformation after the 2004 Sumatra Andaman earthquake", Geochem. Geophys. Geosyst.,11, Q06008, 2010.

[15]F. Fatolazadeh, B. Voosoghi, M. Raoofian Naeeni, "Correction of hydrological and oceanic effects from GRACE coefficients by combination of the steric sea level data, altimetry data and GLDAS model", Actageophys, Accept, 2015.

[16]L. Wang, C. K. Shum, C. Jekeli, "Gravitational gradient changes following the Summatra-Andaman earthquake inferred from GRACE”Geophys. J. Int., 191, 110911, 2012.

[17]L.Wang, C. K. Shum, F. J.Simons, A. Tassara, K. Erkan, C. Jekeli, A. Braun, C. Y.Kuo, H. Lee, D. Y.Yuan, "Coseismic slip of the $2010 \mathrm{Mw} 8.8$ Great Maule, Chile Earthquake quantified by GRACE observation"Earth\&Planet. Sci. Lett., 335, 167- 179, 2012. 


\title{
Localization of gravity signals due to gravimetric satellite
}

\author{
Farzam Fatolazadeh ${ }^{1}$, Mehdi Raoofian Naeeni ${ }^{2}$, Behzad Vosooghi $^{3}$, Mahmood Mohebi $^{4}$, Rahim Javadi Azar $^{5}$
}

1- Msc Graduate, Department of Geodesy, Faculty of Geodesy and Geomatics Engineering, K. N. Toosi university of technology, 2- Assistant Prof. Department of Geodesy, Faculty of Geodesy and Geomatics Engineering, K. N. Toosi university of Technology

3- Associate Prof. Department of Geodesy, Faculty of Geodesy and Geomatics Engineering, K. N. Toosi university of Technology

4- Master Expert, Deputy Director, National Geographic organization, Iran

\begin{abstract}
In this study, in order to eliminate the stripping error from GRACE gravity observations and localization of the signals of this satellite, wavelet analysis instead of Gaussian isotropic filtering approach is used. For this purpose, the scaling functions and wavelets, generated by a so-called cubic polynomial (CuP), are considered and gravity variations for two major earthquakes-Sumatra earthquake and Maule earthquake- are obtained. For the case of Sumatra earthquake- Indonesia, various scale function of CuP are tested and the most precise results of gravity variations with maximum 30 Micro-Gal is acquired in scale 4 which was similar to other studies. This result didn't change with increasing scale function even higher than 4 . Moreover, for the case of Maule earthquake- Chile, the gravity variations before and after of using wavelet is attained which shows many disparity. The maximum gravity variations before applying wavelet is acquired 20 Micro-Gal and after applying that, the maximum of these variations is computed 10 Micro-Gal which was similar to other researches.
\end{abstract}

Key words: Wavelet analysis, GRACE observations, ,Sumatra earthquake, Maule earthquake.Gaussian filtering.

Correspondence Address : Department of Geodesy Faculty of Geodesy and Geomatics Eng., K.N.Toosi University of Technology Vali_Asr St., Mirdamad Cross, Tehran, Iran.

Tel : +98 9125646641

Email : mraoofian@kntu.ac.ir 